\title{
Impact of Obesity Visceral Adiposity and Metabolic Syndrome on Male Fertility
}

\author{
Esra Bahar GUR 1 , Ebru SAHIN GULEC ${ }^{2}$, Sadik INCE 3 , Mehmet Zeynel KESKIN", Ahmet DEMIR², Baris SENGUL 6 , \\ Mehmet Serkan GUR ${ }^{5}$ \\ Izmir, Turkey
}

\begin{abstract}
OBJECTIVE: The study aimed to assess the association between the separate anthropometric indexes including visceral adiposity and metabolic syndrome on male fertility.

STUDY DESIGN: In a cross-sectional study, the visceral and subcutaneous fat thickness of 162 participants were measured by ultrasonography. Participants' body mass index, waist circumference, and waist/hip ratio were determined. Participants' biochemical metabolic parameters and reproductive hormones were measured and semen parameters were recorded. Participants were divided into groups according to body mass index and different percentiles of the visceral fat thickness. Differences between groups were investigated by One-way ANOVA, Kruskal-Wallis $\mathrm{H}$, and Pearson Chi-Square test. The relationship between anthropometric measurements and sperm parameters was evaluated by Pearson and Spearman's rank correlation test. The effect of anthropometric indexes on sperm parameters was evaluated using multivariate regression analysis.
\end{abstract}

RESULTS: It was seen that only total testosterone of sex hormones decreased significantly in the obesity group $(p=0.003)$. There was a significant and reverse association between visceral fat thickness with sperm morphology ( $r h o=-0.2, p=0.01$ ). There was no significant correlation between semen parameters and other anthropometric measurements. In multiple regression analysis, the effect of anthropometric measurements, including visceral fat thickness, on semen parameters was not found, but only smoking was found to be a factor affecting sperm concentration, progressive motility, and morphology $(p=0.03$, $p=0.03$, and $p=0.01$ ).

CONCLUSION: In this study, it was shown that increased obesity was associated with low testosterone levels and increased visceral fat was associated with abnormal sperm morphology. More extensive studies are required on this subject.

Keywords: Male fertility, Obesity, Sperm parameters, Visceral adiposity

Gynecol Obstet Reprod Med 2021;27(3):260-267

${ }^{1}$ Department of Obstetrics and Gynecology, Izmir Katip Celebi University School of Medicine, Izmir, Turkey.

2 Department of Obstetrics and Gynecology, SBU Tepecik Education and Research Hospital, Izmir, Turkey.

${ }^{3}$ Department of Radiology, SBU Tepecik Education and Research Hospital, Izmir, Turkey.

${ }^{4}$ Department of Urology, SBU Tepecik Education and Research Hospital, Izmir, Turkey.

${ }_{5}$ Department of Radiology, Izmir Katip Celebi University School of Medicine, Izmir, Turkey.

${ }^{6}$ Tinaztepe Hospital, Torbali, Izmir, Turkey.

Address of Correspondence: Esra Bahar Gur

Department of Obstetrics and Gynecology, Izmir Katip Celebi University School of

Medicine, Izmir, Turkey.

esrabaharg@yahoo.com

Submitted for Publication: 29.09.2020 Revised for Publication: 28.12.2020 Accepted for Publication: 12.03.2021 Online Published: 25.02.2021

ORCID IDs of the authors: $\quad$ EBG: 0000-0002-1976-8795

ESG: 0000-0003-0327-5707, SI: 0000-0002-7713-4563

MZK: 0000-0002-9206-5586, AD: 0000-0003-3811-1606

BS: 0000-0001-9636-8659, MSG: 0000-0002-4580-4227

\begin{tabular}{|c|c|}
\hline \multirow{3}{*}{ 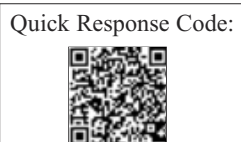 } & Access this article online \\
\hline & $\begin{array}{l}\text { Website: www.gorm.com.tr } \\
\text { e- mail: info@gorm.com.tr }\end{array}$ \\
\hline & DOI:10.21613/GORM.2021.1156 \\
\hline
\end{tabular}

\section{Introduction}

Obesity, which is considered an epidemic disease nowadays, is related not only to chronic medical conditions but also to reproductive problems in both women and men $(1,2)$. Although the results are contradictory, several studies have reported inverse correlations of male subfertility with obesity. A recent study concluded that the odds of infertility increase by $10 \%$ for every $9 \mathrm{~kg}$ (20 pounds) in overweight men (3).

Male infertility can be caused by a wide variety of conditions, including anatomical or genetic abnormalities, systemic or neurological diseases, infections, trauma, sperm antibodies, and gonadal toxins. However, in about half of the cases, the cause of infertility cannot be found (4). It is important to investigate lifestyles and modifiable factors, especially in these groups.

How to cite this article: Gur EB. Sahin Gulec E. Ince S. Keskin MZ. Demir A. Sengul B. Gur MS. Impact of Obesity Visceral Adiposity and Metabolic Syndrome on Male Fertility. Gynecol Obstet Reprod Med 2021;27(3):260-267 
The mechanisms underlying subfertility or infertility in obese men are not clearly known. But, these mechanisms have been shown to be associated with sexual dysfunction, increased sperm DNA damage, and endocrine changes (4-7). Additionally, hyperglycemia and metabolic syndrome, which are common occurrences in obese individuals may contribute to impaired spermatogenesis by increasing the sex hormonebinding protein and reducing testosterone level (8).

When determining metabolic risk factors, body fat distribution has been thought to be more important than the overall fatty mass. Fat storage in the abdominal zone, and particularly in the visceral compartment, has been more strongly linked to metabolic disease (9-11). Visceral adiposity is often characterized by oxidative stress, a condition in which an imbalance occurs between the production and inactivation of reactive oxygen species (12). On the other hand, sperm oxidative stress has been associated with decreased sperm motility, increased sperm DNA damage, and decreased acrosome reaction (13).

Recently, studies have shown that the increase in the rate of central fat is significantly and negatively related to sperm count and sperm morphology (14-17). However, the association with visceral adiposity and sperm quality remains unknown (18).

In the treatment of infertile couples with male factor, intrauterine insemination or in-vitro fertilization (IVF) and intracytoplasmic sperm injection (ICSI) are preferred according to the degree of the problem and, in most cases, the underlying cause of the patient's reduced fertility can never be identified or treated. Therefore, research into potentially modifiable risk factors may ultimately lead to more cost-effective, preventative, and curative treatments. In this study, we aimed to assess the relationship between anthropometric measurements including visceral adiposity and sperm parameters.

\section{Material and Method \\ Study population}

This cross-sectional study was conducted at the University of Health Sciences Tepecik Training and Education Hospital, Izmir, Turkey between January 2017 and September 2017. This study was conducted with the approval of the local Ethics Committee and was in compliance with the 1975 Helsinki Declaration (revised in 2008) (IRB approval: 22.2.2017/55).

The participants were the male partners of women who applied to the gynecology outpatient clinic for pre-pregnancy counseling. Two hundred and eighteen volunteer male subjects aged between 18-45 years were included in the study. After informed consent was obtained, volunteers were subjected to physical and systemic examinations. Exclusion criteria included apparent genital infection, erectile dysfunction, uncontrolled diabetes mellitus, uncontrolled hypertension, severe cerebrovascular or cardiovascular disease, and chronic drug therapy. After sperm samples were analyzed, azoospermia was detected in two samples. Fifty-four participants were excluded from the study according to exclusion criteria. Ultimately, the data of 162 participants were analyzed (Figure 1).

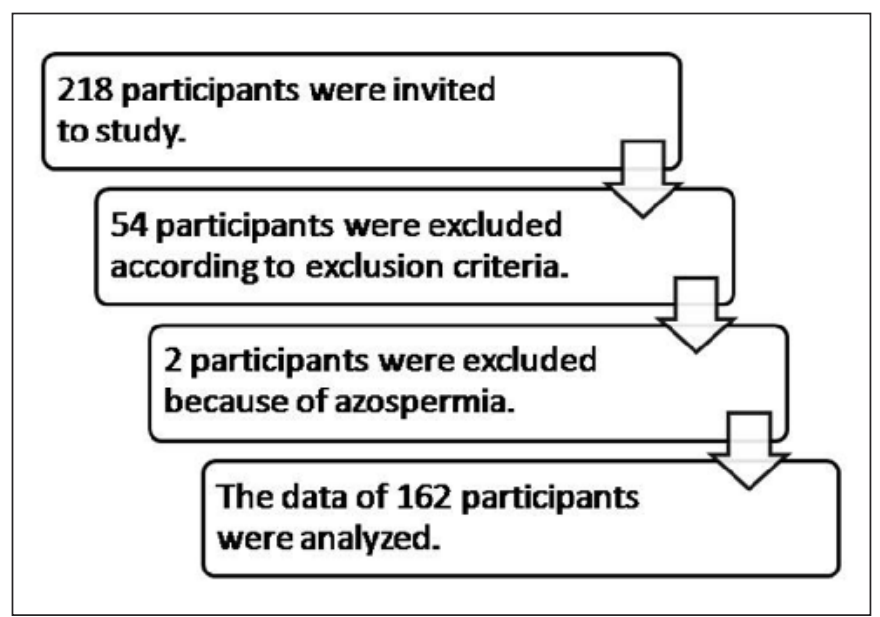

Figure 1: Flow chart of the study

\section{Sperm collection and analysis}

Semen samples were collected via masturbation in a special room near the laboratory and the samples were analyzed within one hour. The period of sexual abstinence was recorded. All the sperm samples were kept in a $37^{\circ} \mathrm{C} \mathrm{CO}_{2}$ incubator to allow them to liquefy and facilitate routine sperm analysis as described in the World Health Organization Manual of 2010 (17). The observations and counting during the sperm analyses were automatic, and the origins of specimens were blinded to avoid bias (Spermalite/SQA-V; Medical Electronic Systems Ltd, Caesarea Industrial Park, Israel). Sperm concentration (concentration/ml), progressive motility (\% proportion of WHO type A + B motility), and sperm morphology (according to Cruger criteria) were recorded.

\section{Biochemical and hormonal measurements}

Venous blood was taken before breakfast in the morning for biochemical and hormonal assessment. Serum luteinizing hormone (LH), follicle-stimulating hormone (FSH), prolactin (Prl), estrogen, and testosterone levels were measured by the Enzyme-linked immunosorbent assay (ELISA) method (Diagnostics Systems Laboratories, Webster, Texas, USA). Fasting blood glucose (FBG), low-density lipoprotein (LDLC), high-density lipoprotein (HDL-C), and triglyceride (TG) levels were measured. They were processed for FBG using Enzymatic Hexokinase, plasma lipids: LDL-C, HDL-C, and TG using an enzymatic colorimetric method. All tests were performed in a COBAS 6000 (Roche Diagnostics, Rotkreuz, Switzerland) analyzer.

\section{Anthropometric measurements}

Body mass index was calculated by measuring the height and the bodyweight [weight $(\mathrm{kg}) /$ height $\left.(\mathrm{m})^{2}\right]$. WC was determined by measuring from the middle point of the border of the 
iliac crest to the last rib after normal expiration with the participant in the standing position. Hip circumference (HC) was measured in $\mathrm{cm}$ around the widest portion of the buttocks. Waist to hip ratio (WHR) was determined by dividing the measured waist circumference (WC) by the measured HC.

\section{Ultrasonographic assessment}

Ultrasonographic measurements were performed by two radiologists (S.I. and M.S.G) with the probe over the abdomen using a high-resolution ultrasound system (Siemens; Acuson Anteres, Mountain View, CA 94043, USA and a VFX 9-4$\mathrm{MHz}$ linear transducer). All of the measurements were taken in the supine position and after inspiration so that inspirationbased abdominal wall tension could be excluded. The maximum pre-peritoneal visceral fat (Vmax, VFT) and minimum subcutaneous fat (Smin, SFT) were measured from the point where the subcutaneous fatty tissue was minimal. It was determined by performing a longitudinal scan along the linea alba from to the umbilicus using the linear probe. The VFT was defined as the fat thickness between the liver surface and the linea alba, and the SFT was defined as the fat thickness between the skin and the linea alba (Figure 2) (18). Forty out of 162 scans were examined by two blinded observers, by two radiologists (S.I. and M.S.G) and forty randomly selected participants were examined twice by one-week interval by the same investigator (S.I.), to test the study reliability. The intraobserver reproducibility (S.I.) of the ultrasonographic measurements was $1.5-2.0 \%$ for VFT and $1.8-3.2 \%$ for SFT. The reproducibility between the two operators was $1.8-2.2 \%$ for VFT and $2.5-2.7 \%$ for SFT.

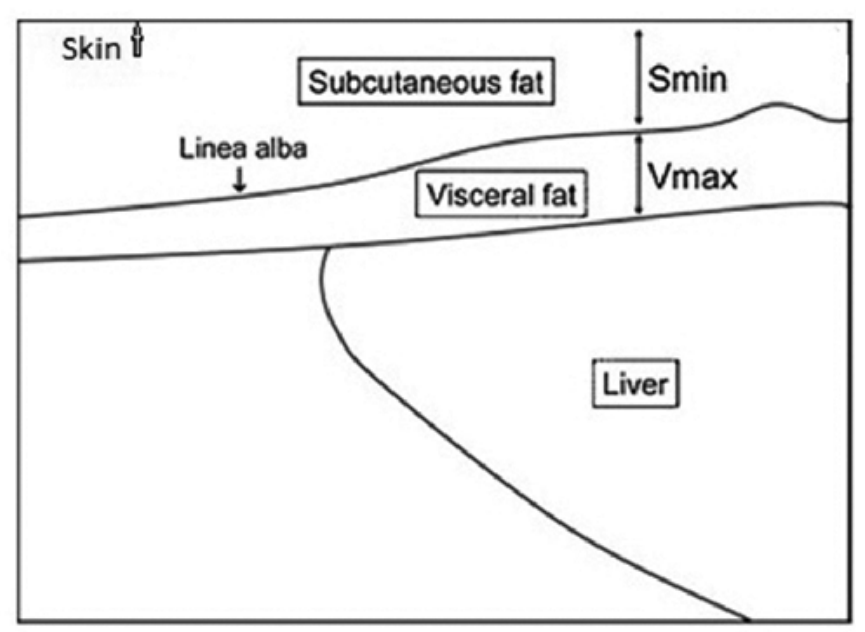

Figure 2: Measurement of the visceral fat thickness (18)

\section{Metabolic syndrome}

Metabolic syndrome is defined according to the criteria of the International Diabetes Federation, 2005 (19). According these criteria, increased WC $(\geq 94 \mathrm{~cm})$, hyperlipidemia (TG>150 mg/dL, HDL-C40 mg/dL), FPG $\geq 100 \mathrm{mg} / \mathrm{dL}$ and hypertension $(\geq 130 / 85 \mathrm{mmHg}$ or on antihypertensive medications); the presence of increased $\mathrm{WC}+$ any other two risk factors are necessary for the diagnosis of metabolic syndrome.

\section{Statistical analysis}

Statistical analyzes were performed using IBM SPSS (24.0) for Windows. One-way ANOVA, Kruskal-Wallis H analysis, and Pearson Chi-Square Test were used to determine any statistically significant differences between BMI and VFT groups $(\mathrm{BMI} \leq 25,25-30$, and $\geq 30$; VFT $<10,10-90,>90$ percentiles). Correlation between anthropometric parameters and semen parameters was investigated using Spearman's rank and Pearson Correlation tests. The factors affecting semen parameters were investigated by multiple regression analysis. $p<0.05$ was considered significant.

\section{Results}

The data of 162 participants were analyzed. There was no significant difference between the groups in terms of age, smoking, and alcohol use. In terms of biochemical metabolic markers, only the increased VFT group had significantly lower HDL-C levels $(p=0.04)$. Whereas biochemical metabolic markers were similar between different BMI groups. WC, WHR, SFT, and VFT were significantly higher in both the increased BMI and increased VFT groups $(p<0.01,0.01$, $<0.01,0.02,<0.01,0.03,0.04,<0.01$, respectively). The incidence of metabolic syndrome was significantly different between VFT groups $(p=0.01)$. Only total testosterone was found to be significantly decreased among the sex hormones in the obesity group $(p=0.003)$ (Table I). There was a significant and reverse association between VFT with sperm morphology $(\mathrm{rho}=-0.2, p=0.01)$. There was no significant correlation between semen parameters and other anthropometric measurements (Table II). None of the anthropometric measurements, including VFT, had an effect on semen parameters in multiple regression analysis. On the other hand, smoking was found to be a factor affecting sperm concentration, progressive motility, and morphology $(p=0.03, p=0.03$, and $p=0.01$ ) (Table III).

\section{Discussion}

In the last hundred years, it has been shown that the number and quality of sperm have gradually decreased around the world. Although the reason for this deterioration in sperm parameters is not known clearly, it is thought that increasing obesity affects this process (20). Although many studies show the effect of obesity on male fertility in the literature, the results of these studies are confusing. Moreover, the majority of these studies were made between male partners of infertile couples. In the present study, we hypothesized that visceral adiposity and metabolic syndrome might be independent factors on male fertility. We found that increased obesity was associated with low testosterone levels and increased visceral fat was associated with abnormal sperm morphology $(p=0.003$ and $=0.01)$.

In the literature of the last decade, three meta-analyses have evaluated the relationship between obesity and semen 
Table la: Characteristics of study population according to the different body mass index groups

\begin{tabular}{|c|c|c|c|c|}
\hline & $\begin{array}{l}\text { BMI } \leq 25 \\
n=56\end{array}$ & $\begin{array}{l}\text { BMI 25-30 } \\
n=80\end{array}$ & $\begin{array}{l}B M I \geq 30 \\
n=26\end{array}$ & $p$ \\
\hline Age (years) & $32.21 \pm 5.71$ & $32.70 \pm 5.55$ & $34.77 \pm 6.15$ & $0.402^{+}$ \\
\hline \multicolumn{5}{|l|}{ Mean $\pm S D$} \\
\hline \multicolumn{5}{|l|}{ Smoking (number/day) } \\
\hline Median (Q1-Q3) & $6.96(0-11.5)$ & $7.48(0-15)$ & $5.00(0-11.5)$ & $0.532^{*}$ \\
\hline \multicolumn{5}{|l|}{ Alcohol use } \\
\hline$+\mathrm{n}(\%)$ & $10(17.9)$ & $8(10)$ & $2(7.7)$ & $0.591^{++}$ \\
\hline$-n(\%)$ & $46(82.1)$ & $72(90)$ & $24(92.3)$ & \\
\hline \multicolumn{5}{|c|}{ Metabolic biochemical markers } \\
\hline Glucose (mg/dL) & 94.5 & 101 & 101 & $0.402^{+}$ \\
\hline Median (Q1-Q3) & $(89-108.5)$ & $(94-108)$ & $(88.5-111.5)$ & \\
\hline TG (mg/dL) & 133 & 160 & 156 & $0.532^{*}$ \\
\hline Median (Q1-Q3) & $(91.5-184.7)$ & $(97-276)$ & $(107-22.5)$ & \\
\hline HDL-C (mg/dL) & 44 & 39 & 39 & $0.591^{++}$ \\
\hline Median (Q1-Q3) & $(36.2-48)$ & $(34-44)$ & $(34-44)$ & \\
\hline LDL-C (mg/dL) & 113.5 & 119 & 99 & $0.402^{+}$ \\
\hline Median (Q1-Q3) & $(99.2-135.7)$ & $(100-147)$ & $(88-134)$ & \\
\hline \multicolumn{5}{|c|}{ Anthropometric measurements } \\
\hline WC (cm) & $86.64 \pm 5.81^{\mathrm{a}}$ & $96.70 \pm 7^{b}$ & $106.08 \pm 5.43^{c}$ & $<0.001^{+}$ \\
\hline WHR & $0.89 \pm 0.03^{a}$ & $0.91 \pm 0.04^{a}$ & $0.95 \pm 0.03^{b}$ & $0.001^{+}$ \\
\hline $\mathrm{SFT}(\mathrm{mm})$ & 8.3 & 10.4 & 14.1 & $<0.001^{*}$ \\
\hline Median (Q1-Q3) & $(6.95-10.02)^{a}$ & $(8.95-12.32)^{b}$ & $(10.55-18.4)^{b}$ & \\
\hline VFT (mm) & 13.9 & 19.35 & 22.8 & $0.002^{*}$ \\
\hline Median (Q1-Q3) & $(10.8-20.35)^{a}$ & $(14.55-23.87)^{b}$ & $(18.3-24.45)^{b}$ & \\
\hline \multicolumn{5}{|l|}{ Metabolic syndrome } \\
\hline$+\mathrm{n}(\%)$ & $4(7.1)$ & $24(30)$ & $12(46.2)$ & $0.328^{++}$ \\
\hline$-\mathrm{n}(\%)$ & $52(92.9)$ & $56(70)$ & $14(53.8)$ & \\
\hline \multicolumn{5}{|l|}{ Sex hormones } \\
\hline $\mathrm{FSH}(\mathrm{mlU} / \mathrm{mL})$ & 6.05 & 6.77 & 8.08 & $0.063^{*}$ \\
\hline Median (Q1-Q3) & $(3.72-6.05)$ & $(2.7-7.3)$ & $(4.2-8.85)$ & \\
\hline $\mathrm{LH}(\mathrm{mlU} / \mathrm{mL})$ & 5.06 & 5.27 & 5.51 & $0.722^{*}$ \\
\hline Median (Q1-Q3) & $(3.55-7.05)$ & $(3.2-5.6)$ & $(3.2-6.7)$ & \\
\hline $\operatorname{Prl}(\mathrm{ng} / \mathrm{mL})$ & 9.6 & 9.91 & 8.53 & $0.583^{*}$ \\
\hline Median (Q1-Q3) & $(7.02-12.12)$ & $(6.5-10.6)$ & $(6.5-9.85)$ & \\
\hline Testosterone (nmol/L) & 399.09 & 312.17 & 304.138 & $0.003^{*}$ \\
\hline Median (Q1-Q3) & $(302.32-472.67)^{a}$ & $(253-353.2)^{b}$ & $(246.15-363.35)^{b}$ & \\
\hline Estrogen (pg/mL) & 27.61 & 31.85 & 20.23 & $0.083^{*}$ \\
\hline Median (Q1-Q3) & $(20-23.5)$ & $(20-42)$ & $(20-20)$ & \\
\hline \multicolumn{5}{|l|}{ Semen analysis } \\
\hline Sperm concentration (ml) & 40 & 40 & 25 & $0.664^{*}$ \\
\hline Progressive motility & $(16-60)$ & $(14.25-66.5)$ & $(3-77.5)$ & $0.551^{+}$ \\
\hline$(a+b . \%)$ & $36.96 \pm 18.78$ & $32.73 \pm 19.54$ & $30.77 \pm 19.48$ & \\
\hline Morphology (\%) & 2.5 & 3 & 1 & $0.549^{*}$ \\
\hline (mean rank) & $(0-5)$ & $(2-5)$ & $(0.5-4.5)$ & \\
\hline
\end{tabular}

+One-way ANOVA; *Kruskal Wallis Analysis; ++Pearson Chi-Square Test BMI: Body Mass Index, LH: Luteinizing hormone, FSH: Follicle-stimulating hormone, Prl: Prolactin, TG: Triglyceride, HDL-C: High-density lipoprotein, LDL-C: Low-density lipoprotein, VFT: Visceral fat thickness, SFT: Subcutaneous fat thickness. A value of $p<0.05$ was considered significant. 
Table Ib: Characteristics of study population according to the different visceral fat thickness groups

\begin{tabular}{|c|c|c|c|c|}
\hline & $\begin{array}{l}\text { VFT } \\
<\% 10 \text { percentile } \\
n=16\end{array}$ & $\begin{array}{l}\text { VFT } \\
\% 10-90 \text { percentile } \\
n=128\end{array}$ & $\begin{array}{l}\text { VFT } \\
>\% 90 \text { percentile } \\
n=18\end{array}$ & $p$ \\
\hline Age (years) Mean $\pm S D$ & $30.88 \pm 5.61$ & $32.92 \pm 5.66$ & $34.22 \pm 6.24$ & $0.480^{+}$ \\
\hline \multicolumn{5}{|l|}{ Smoking (number/day) } \\
\hline $\begin{array}{l}\text { Alcohol use } \\
+\mathrm{n}(\%) \\
-\mathrm{n}(\%)\end{array}$ & $\begin{array}{l}4(25) \\
12(75)\end{array}$ & $\begin{array}{l}16(12.5) \\
112(87.5)\end{array}$ & $\begin{array}{l}0(0) \\
18(100)\end{array}$ & $0.314^{++}$ \\
\hline $\begin{array}{l}\text { Metabolic biochemical mark } \\
\text { Glucose (mg/dL) } \\
\text { Median (Q1-Q3) }\end{array}$ & $\begin{array}{l}97 \\
(92.5-111.5)\end{array}$ & $\begin{array}{l}101 \\
(89-109)\end{array}$ & $\begin{array}{l}96 \\
(82-99.5)\end{array}$ & $0.366^{*}$ \\
\hline $\begin{array}{l}\text { TG }(\mathrm{mg} / \mathrm{dL}) \\
\text { Median (Q1-Q3) }\end{array}$ & $\begin{array}{l}122 \\
(72.5-216)\end{array}$ & $\begin{array}{l}145 \\
(102-224)\end{array}$ & $\begin{array}{l}164 \\
(111.5-245)\end{array}$ & $0.482^{*}$ \\
\hline $\begin{array}{l}\text { HDL-C (mg/dL) } \\
\text { Median (Q7-Q3) }\end{array}$ & $\begin{array}{l}48.5 \\
(40-53.5)^{a}\end{array}$ & $\begin{array}{l}39 \\
(34-44)^{b}\end{array}$ & $\begin{array}{l}38 \\
(34-45.5)^{\mathrm{b}}\end{array}$ & $0.046^{*}$ \\
\hline $\begin{array}{l}\text { LDL-C (mg/dL) } \\
\text { Median (Q1-Q3) }\end{array}$ & $\begin{array}{l}110 \\
(86.75-121.5)\end{array}$ & $\begin{array}{l}115 \\
(98-140)\end{array}$ & $\begin{array}{l}137 \\
(110-165.5)\end{array}$ & $0.165^{\star}$ \\
\hline \multicolumn{5}{|l|}{ Anthropometric measurements } \\
\hline WC $(\mathrm{cm})$ & $\begin{array}{l}82 \\
(76.25-86)^{a}\end{array}$ & $\begin{array}{l}94.5 \\
(88-100.75)^{b}\end{array}$ & $\begin{array}{l}103 \\
(98-107)^{c}\end{array}$ & $<0.001^{*}$ \\
\hline WHR & $\begin{array}{l}0.87 \\
(0.83-0.89)^{a}\end{array}$ & $\begin{array}{l}0.91 \\
(0.88-0.95)^{b}\end{array}$ & $\begin{array}{l}0.93 \\
(0.91-0.96)^{b}\end{array}$ & $0.003^{*}$ \\
\hline $\begin{array}{l}\text { SFT }(\mathrm{mm}) \\
\text { Median (Q1-Q3) }\end{array}$ & $\begin{array}{l}6.5 \\
(4.95-10.8)^{a}\end{array}$ & $\begin{array}{l}9.9 \\
(8.32-12.4)^{\mathrm{ab}}\end{array}$ & $\begin{array}{l}12.1 \\
(11.35-17)^{b}\end{array}$ & $0.004^{*}$ \\
\hline $\begin{array}{l}\text { VFT (mm) } \\
\text { Median (Q1-Q3) }\end{array}$ & $\begin{array}{l}8.6 \\
(6.1-9.42)^{a}\end{array}$ & $\begin{array}{l}18.65 \\
(14.02-21.25)^{b}\end{array}$ & $\begin{array}{l}29 \\
(26.95-31.45)^{c}\end{array}$ & $<0.001^{\star}$ \\
\hline \multicolumn{5}{|l|}{ Metabolic syndrome } \\
\hline $\begin{array}{l}+\mathrm{n}(\%) \\
-\mathrm{n}(\%)\end{array}$ & $\begin{array}{l}2(12.5) \\
14(87.5)\end{array}$ & $\begin{array}{l}30(23.4) \\
98(76.6)\end{array}$ & $\begin{array}{l}8(44.4) \\
10(55.6)\end{array}$ & $0.012^{++}$ \\
\hline \multicolumn{5}{|l|}{ Sex hormones } \\
\hline $\begin{array}{l}\text { FSH (mIU/mL) } \\
\text { Median (Q1-Q3) }\end{array}$ & $\begin{array}{l}6.9 \\
(2.8-22.94)\end{array}$ & $\begin{array}{l}4.3 \\
(3-6.1)\end{array}$ & $7.4(3.2-8.8)$ & $0.198^{*}$ \\
\hline $\begin{array}{l}\mathrm{LH}(\mathrm{mlU} / \mathrm{mL}) \\
\text { Median (Q1-Q3) }\end{array}$ & $\begin{array}{l}5.05 \\
(3.8-8.85)\end{array}$ & $\begin{array}{l}4.1 \\
(3.2-5.7)\end{array}$ & $4.4(3.5-7.2)$ & $0.350^{*}$ \\
\hline $\begin{array}{l}\text { Prl (ng/mL) } \\
\text { Median (Q1-Q3) }\end{array}$ & $\begin{array}{l}8.9 \\
(6.52-12.45)\end{array}$ & $\begin{array}{l}8.2 \\
(6.7-10.8)\end{array}$ & $\begin{array}{l}7.8 \\
(6.8-9.55)\end{array}$ & $0.750^{*}$ \\
\hline $\begin{array}{l}\text { Testosterone (nmol/L) } \\
\text { Median (Q1-Q3) }\end{array}$ & $\begin{array}{l}395.45 \\
(295.7-468.3)\end{array}$ & $\begin{array}{l}316.2 \\
(259.1-381.6)\end{array}$ & $\begin{array}{l}311 \\
(238.7-382.9)\end{array}$ & $0.392^{*}$ \\
\hline $\begin{array}{l}\text { Estrogen (pg/mL) } \\
\text { Median (Q1-Q3) }\end{array}$ & $\begin{array}{l}20 \\
(20-20.5)\end{array}$ & $\begin{array}{l}20 \\
(20-29)\end{array}$ & $\begin{array}{l}20 \\
(20-35.5)\end{array}$ & $0.992^{*}$ \\
\hline \multicolumn{5}{|l|}{ Semen analysis } \\
\hline Sperm concentration $(\mathrm{mL})$ & $\begin{array}{l}46 \\
(0.63-60)\end{array}$ & $\begin{array}{l}37.5 \\
(13.1-63.75)\end{array}$ & $\begin{array}{l}43 \\
(18.5-90)\end{array}$ & $0.551^{*}$ \\
\hline Progressive motility (a+b. \%) & $29 \pm 19.77$ & $35.13 \pm 19.22$ & $24.33 \pm 18.98$ & $0.529^{+}$ \\
\hline $\begin{array}{l}\text { morphology }(\%) \\
\text { (mean rank) }\end{array}$ & $\begin{array}{l}5 \\
(1.75-6.75)\end{array}$ & $\begin{array}{l}3 \\
(1-4.75)\end{array}$ & $\begin{array}{l}2 \\
(1.5-4)\end{array}$ & $0.107^{*}$ \\
\hline
\end{tabular}

+One-way ANOVA, *Kruskal Wallis Analysis, ++Pearson Chi-Square test

BMI: Body mass index, LH: Luteinizing hormone, FSH: Follicle-stimulating hormone, Prl: Prolactin, TG: Triglyceride, HDL-C: High-density lipoprotein, LDL-C: Low-density lipoprotein, VFT: Visceral fat thickness, SFT: Subcutaneous fat thickness. A value of $p<0.05$ was considered significant. 
Table II: Correlation of sperm parameters and anthropometric measurements

\begin{tabular}{lccc}
\hline & Concentration & $\begin{array}{c}\text { \% Progressive } \\
\text { Motility }\end{array}$ & \%orphology \\
\hline BMI CC & 0.003 & -0.089 & -0.043 \\
$p$ & $0.980^{*}$ & $0.427^{+}$ & $0.704^{*}$ \\
WHR CC & & -0.089 & -0.183 \\
$p$ & -0.026 & $0.432^{+}$ & $0.102^{*}$ \\
SFT CC & $0.815^{*}$ & -0.170 & -0.062 \\
$p$ & & $0.130^{*}$ & $0.580^{*}$ \\
VFT CC & -0.105 & & -0.275 \\
$p$ & $0.350^{*}$ & -0.103 & $0.013^{*}$ \\
\hline
\end{tabular}

BMI: Body mass index, CC: Correlation coefficient, WHR: Waist to hip ratio, VFT: Visceral fat thickness, SFT: Subcutaneous fat thickness, +Pearson Correlation test, *Spearman's rank correlation test. A value of $p<0.05$ was considered significant

Table III: Multiple regression to predict concentration total and progressive motility and morphology

\begin{tabular}{|c|c|c|c|c|c|c|}
\hline & \multicolumn{2}{|c|}{ Concentration } & \multicolumn{2}{|c|}{ Progressive motility } & \multicolumn{2}{|c|}{ Normal morphology } \\
\hline & Standardized & & Standardized & & Standardized & \\
\hline & Coefficients $\beta$ & $p$ & Coefficients $\beta$ & $p$ & Coefficients $\beta$ & $p$ \\
\hline Age & 0.090 & 0.453 & 0.192 & 0.109 & 0.077 & 0.521 \\
\hline Smoking & 0.259 & 0.033 & 0.258 & 0.034 & 0.303 & 0.014 \\
\hline Alcohol & -0.076 & 0.537 & -0.020 & 0.870 & -0.137 & 0.271 \\
\hline Metabolic syndrome & -0.248 & 0.071 & 0.077 & 0.570 & 0.021 & 0.875 \\
\hline BMI & 0.212 & 0.314 & -0.222 & 0.290 & 0.226 & 0.285 \\
\hline WC & 0.038 & 0.897 & 0.383 & 0.194 & -0.094 & 0.749 \\
\hline WC/WHR & 0.084 & 0.662 & -0.338 & 0.081 & -0.082 & 0.670 \\
\hline SFT & -0.194 & 0.166 & -0.106 & 0.446 & 0.000 & 0.998 \\
\hline VFT & 0.032 & 0.823 & -0.087 & 0.544 & -0.260 & 0.074 \\
\hline
\end{tabular}

WC/WHR: Waist circumference Maist to hip ratio, SFT: Subcutaneous fat thickness, VFT: Visceral fat thickness. A value of $p<0.05$ wasconsidered significant

parameters. Mac-Donald and et al. did not show a significant relationship between BMI and sperm parameters in their metaanalysis (6). Another meta-analysis of 21 studies with 13,077 subjects reported a J-shaped association between BMI and abnormal total sperm count: Overweight and obese men had a significantly elevated risk of abnormal sperm count compared to normal-weight men (14). In a recent meta-analysis, it was shown that obese men were more likely to experience infertility $(\mathrm{OR}=1.66,95 \%$ CI 1.53-1.79). Moreover, their rate of live birth per cycle of assisted reproduction technology (ART) was reduced $(\mathrm{OR}=0.65,95 \% \mathrm{CI} 0.44-0.97)$ and they had a $10 \% \mathrm{ab}-$ solute risk increase in a nonviable pregnancy. But, significant differences were not found for conventional semen parameters (21). In our study, we did not find a significant difference between sperm parameters in different BMI groups. However, we found a weak but statistically significant correlation between VFT and sperm morphology ( $\mathrm{rho}=-0.2, p=0.01$ ). Additionally, HDL-C was significantly lower and the inci- dence of metabolic syndrome was higher in the high VFT group ( $p=0.04$ and $=0.01$ ). Some recent studies have shown that WHR and body fat percentage are inversely proportional to sperm parameters (14-17). However, no studies investigating the effect of visceral fat on sperm in the current literature. In recent years, there has been increasing evidence that visceral adiposity may be an important component of metabolic syndrome (22). Therefore, visceral fat may be a more important factor in sperm quality than BMI.

When we evaluate the results of the studies in terms of reproductive hormones, only, testosterone levels were significantly reduced in obese infertile men $(p=0.003)$, and no relationship between VFT and these hormones. Several studies documented that increased male BMI is associated with reduced plasma concentrations of testosterone $(23,24)$. In a metaanalysis of 31 studies, it was shown that there was a strong and inverse relationship between total testosterone and sex hor- 
mone-binding globulin (SHBG) levels and BMI (6). In our study, although total testosterone levels were low in the obesity group, sperm parameters were not affected. This can be explained by several possible mechanisms: Firstly, increased insulin suppresses the production of SHBG from the liver in obese people. Although total testosterone decreased significantly in obese men, decreased free testosterone levels remain milder due to decreased SHBG levels. Secondly, it is possible to maintain some degree of homeostasis of endocrine control of spermatogenesis even in obese men. Additionally, spermatogenesis is not only controlled by hormonal regulation (6).

As far as we know, our study is the first study investigating the effect of visceral fat on sperm parameters. Although we could not find a relationship between visceral fat and sperm count and motility in the study, we think that the hypothesis of the study is strong and should be tested with more comprehensive studies. Another superior aspect of the study is that our study population was fertile male volunteers unlike many studies on this subject. In addition, the method we used to measure visceral fat thickness in our study is the ultrasonographic measurement, which is a simple and relatively inexpensive method without side effects.

There are some limitations of this study. First, the study was carried out with a small sample of men, and broader study participation is needed. Second, we did not examine functional parameters such as the DNA fragmentation index and seminal oxidative stress. Investigation of these parameters may help us to understand the relationship between metabolic syndrome and sperm quality. Finally, different methods for measuring VFT have been described (bioelectrical impedance, dual-energy X-ray absorptiometry, computerized tomography, etc.). We chose ultrasonographic evaluation because it was a cost-effective and practical method without side effects. We did not compare different measurement techniques in our study.

In conclusion, visceral adiposity, which is at the core of metabolic syndrome, seems to have a negative effect on sperm morphology. More extensive studies are required on this subject.

Acknowledgment: We are grateful to all 162 participants and their families who spent their precious time and participated in this research program. We are also thankful for the tireless efforts of the research team members. This study has been presented at TAJEV 2018 congress as an oral presentation date of 28/04/2018.

Conflict of interests: The authors declare that they have no conflict of interests.

Funding: None

Ethics approval and consent to participate: All participants signed informed written consent before being enrolled in the study.

Availability of data and materials: The data supporting this study is available through the corresponding author upon rea- sonable request.

Authors' contributions: Study concept and design: EBG; acquisition of data: $E S G, M Z K$; analysis and interpretation of data: $E B G$; drafting of the manuscript: $M S G$ and EBG; critical revision of the manuscript: $A D$; statistical analysis: $E B G$; obtained funding: MZK, SI, BS; administrative, technical, or material support: $M S G$; and study supervision: EBG. All authors contributed to the writing of the paper, and have read and approved the final manuscript.

\section{References}

1. Eskandar M, Al-Asmari M, Babu Chaduvula S, AlShahrani M, Al-Sunaidi M, Almushait M, et al. Impact of male obesity on semen quality and serum sex hormones. Adv Urol. 2012;2012:407601. Doi:10.1155/2012/407 601.

2. Must A, Spadano J, Coakley EH, Field AE, Colditz G, Dietz WH. The disease burden associated with overweight and obesity. JAMA. 1999;282(16):1523-9. Doi:10.1001/ jama.282.16.1523.

3. Sallmén M, Sandler DP, Hoppin JA, Blair A, Baird DD. Reduced fertility among overweight and obese men. Epidemiology. 2006;17(5):520-3. Doi:10.1097/01.ede.00 00229953.76862.e5.

4. Katib A. Mechanisms linking obesity to male infertility: Cent European J Urol. 2015;68(1):79-85. Doi:10.5173/ ceju.2015.01.435.

5. Kort HI, Massey JB, Elsner CW, Mitchell-Leef D, Shapiro DB, Witt MA, et al. Impact of body mass index values on sperm quantity and quality. J Androl. 2006;27 (3):450-2. Doi:10.2164/jandrol.05124.

6. MacDonald AA, Herbison GP, Showell M, Farquhar CM. The impact of body mass index on semen parameters and reproductive hormones in human males: a systematic review with meta-analysis. Hum Reprod Update. 2010; 16(3):293-311. Doi:10.1093/humupd/dmp047.

7. Paul C, Murray AA, Spears N, Saunders PT. A single, mild, transient scrotal heat stress causes DNA damage, subfertility and impairs formation of blastocysts in mice. Reproduction. 2008;136(1):73-84. Doi:10.1530/REP-080036.

8. Haring R, Völzke H, Felix SB, Schipf S, Dörr M, Rosskopf D, et al. Prediction of metabolic syndrome by low serum testosterone levels in men: results from the study of health in Pomerania. Diabetes. 2009;58(9):202731. Doi:10.2337/db09-0031.

9. Vermeulen A, Kaufman JM, Deslypere JP, Thomas G. Attenuated luteinizing hormone (LH) pulse amplitude but normal LH pulse frequency, and its relation to plasma androgens in hypogonadism of obese men. J Clin Endocrinol Metab. 1993;76(5):1140-6. Doi:10.1210/ jcem.76.5.8496 304 . 
10. Kerr JB, Millar M, Maddocks S, Sharpe RM. Stage-dependent changes in spermatogenesis and Sertoli cells in relation to the onset of spermatogenic failure following withdrawal of testosterone. Anat Rec. 1993;235(4):54759. Doi:10.1002/ar.1092350407.

11. Gustat J, Elkasabany A, Srinivasan S, Berenson GS. Relation of abdominal height to cardiovascular risk factors in young adults: the Bogalus a heart study. Am J Epidemiol. 2000;151(9):885-91. Doi:10.1093/oxfordjournals.aje.a010292.

12. Fain JN, Madan AK, Hiler ML, Cheema P, Bahouth SW. Comparison of the release of adipokines by adipose tissue, adipose tissue matrix, and adipocytes from visceral and subcutaneous abdominal adipose tissues of obese humans. Endocrinology. 2004;145(5):2273-82. Doi:10.1210/en. 2003-1336.

13. Zorn B, Vidmar G, Meden-Vrtovec H. Seminal reactive oxygen species as predictors of fertilization, embryo quality and pregnancy rates after conventional in vitro fertilization and intracytoplasmic sperm injection. Int J Androl. 2003;26(5):279-85. Doi:10.1046/j.1365-2605.2003.00 424.x.

14. Sermondade N, Faure C, Fezeu L, Shayeb AG, Bonde JP, Jensen TK, et al. BMI in relation to sperm count: an updated systematic review and collaborative meta-analysis. Hum Reprod Update. 2013;19(3):221-31. Doi:10.1093/ humupd/dms050.

15. Belloc S, Cohen-Bacrie M, Amar E, Izard V, Benkhalifa M, Dalléac A, et al. High body mass index has a deleterious effect on semen parameters except morphology: results from a large cohort study. Fertil Steril. 2014;102 (5):1268-73. Doi:10.1016/j.fertnstert.2014.07.1212.

16. Lu JC, Jing J, Dai JY, Zhao AZ, Yao Q, Fan K, et al. Body mass index, waist-to-hip ratio, waist circumference and waist-to-height ratio cannot predict male semen quality: a report of 1231 subfertile Chinese men. Andrologia.
2015;47(9):1047-54. Doi:10.1111/and.12376.

17. Fejes I, Koloszár S, Szöllosi J, Závaczki Z, Pál A. Is semen quality affected by male body fat distribution? Andrologia. 2005;37(5):155-9. Doi:10.1111/j.1439-0272. 2005.00671.x.

18. Gur EB, Ince O, Turan GA, Karadeniz M, Tatar S, Celik E, et al. Ultrasonographic visceral fat thickness in the first trimester can predict metabolic syndrome and gestational diabetes mellitus. Endocrine. 2014;47(2):478-84. Doi: 10.1007/s12020-013-0154-1.

19. ParikhRM, Mohan V. Changing definitions of metabolic syndrome. Indian J Endocrinol Metab. 2012;16(1):7-12. Doi: $10.4103 / 2230-8210.91175$.

20. Campbell JM, Lane M, Owens JA, Bacos HW. Paternal obesity negatively affects male fertility and assisted reproduction outcomes: a systematic review and meta-analysis. Reprod Biomed Online. 2015;31(5):593-604. Doi: 10.1016/j.rbmo.2015.07.012.

21. Mishra P, Negi MPS, Srivastava M, Singh K, Rajender S. Decline in seminal quality in Indian men over the last 37 years. Reprod Biol Endocrinol. 2018;16(1):103. Doi: 10.1186/s12958-018-0425-z.

22. Kumari R, Kumar S, Kant R. An update on metabolic syndrome: Metabolic risk markers and adipokines in the development of metabolic syndrome. Diabetes Metab Syndr. 2019;13(4):2409-17. Doi:10.1016/j.dsx.2019.06.005.

23. Hofny ERM, Ali ME, Abdel-Hafez HZ, Kamal Eel-D, Mohamed EE, Abd El-Azeem HG, et al. Semen parameters and hormonal profile in obese fertile and infertile males. Fertil Steril. 2010;94(2):581-4. Doi:10.1016/j. fertnstert.2009.03.085.

24. Jensen TK, Andersson AM, Jørgensen N, Andersen AG, Carlsen E, Petersen JH, et al. Body mass index in relation to semen quality and reproductive hormones among 1,558 Danish men. Fertil Steril. 2004;82(4):863-70. Doi:10. 1016/j.fertnstert.2004.03.056. 